\title{
INTRACYTOPLASMIC FILAMENTS IN THE CELLS OF ADULT HUMAN ARTICULAR CARTILAGE
}

\author{
BY \\ G. MEACHIM* AND S. ROY \\ Department of Pathology, University of Sheffield
}

The ultrastructure of articular cartilage has been described in the mouse by Silberberg, Silberberg, and Feir (1964) and in the rabbit by Davies, Barnett, Cochrane, and Palfrey (1962), Barnett, Cochrane, and Palfrey (1963), and Palfrey and Davies (1966). From these detailed studies an overall picture has emerged of the ultrastructural pattern of the femoral articular cartilage of the hip joint in mice and of the femoral articular cartilage of the knee joint in rabbits.

The present study concerns the ultrastructure of the articular cartilage of the knee joint in human adults. Observations with the light microscope indicate that the structural pattern of this tissue will be influenced by the layer of the cartilage examined, whether surface layer or deeper layers (Meachim and Collins, 1962), by the amount of regressive change in the surface layer (Meachim, Ghadially, and Collins, 1965), and by the presence or absence of osteoarthritic fibrillation (Collins and McElligott, 1960). Because of these variables an analysis of the overall pattern of the ultrastructure of adult human articular cartilage would be a matter of considerable complexity. Instead it seems to us more profitable to study in turn particular features seen on electron microscopy of this tissue. Previous reports have described intracellular lipid drops in electronmicrographs of human articular cartilage (Collins, Ghadially, and Meachim, 1965), and have dealt with the nature and origin of electron-dense bodies found in the cartilage matrix (Ghadially, Meachim, and Collins, 1965). The present study describes intracytoplasmic filaments in adult human articular chondrocytes, and discusses the relationship between the accumulation of these filaments and the general state of the cartilage cell.

\section{Material and Methods}

Samples of adult human articular cartilage were obtained from the knee joint in nine patients ranging in age from 37 to 83 years. In six of the patients the cartilage was collected at operation before above-knee

\footnotetext{
* Present address: Department of Pathology, University of Liverpool.
}

amputation; in the other three patients the samples were obtained during surgical exploration of the knee joint. Eight of the specimens were taken from the femoral condyle articular cartilage and one from the patella. The exact site or sites sampled in any particular patient varied according to the convenience of the surgeon concerned. The material studied includes areas with an intact articular surface and areas showing various degrees of osteo-arthritic fibrillation.

Small pieces of cartilage were fixed in buffered osmium, processed, and embedded in Araldite. The tissue blocks were sectioned with the ultra-microtome, mounted on copper grids, and stained with lead citrate or uranyl acetate. The sections were examined under the A.E.I. EM6, using an accelerating voltage of 50 or $75 \mathrm{Kv}$. At least eight serial sections were studied from each of the blocks examined; an average of three blocks was cue from each patient.

\section{Results}

Many of the human chondrocytes examined contain one or more areas of finely filamentous material (Figs 1-4). The filaments lie directly within the cytoplasm and are not enclosed in membranebound vacuoles. They are usually perinuclear in situation (Fig. 1, opposite, and Fig. 2, overleaf); much less commonly they are found in a more peripheral part of the cell.

In the electronmicrographs the intracytoplasmic filaments are seen cut in various planes from longitudinal to transverse section. Measurements indicate that their diameter is in the range of 90 to $120 \mathrm{~A}^{\circ}$. The filaments are usually closely packed and tend to be aligned in more or less parallel arrays (Figs 1-4). No evidence of periodicity or of banding was found in the present study, and no evidence of branching was seen. The filaments are apparent both in sections stained with uranyl acetate and in sections stained with lead citrate.

There was no relationship between the presence of cells with cytoplasmic filaments and the general state of the cartilage. Thus cells with filaments have been found both in cartilage samples with an intact articular surface and in samples showing osteo- 


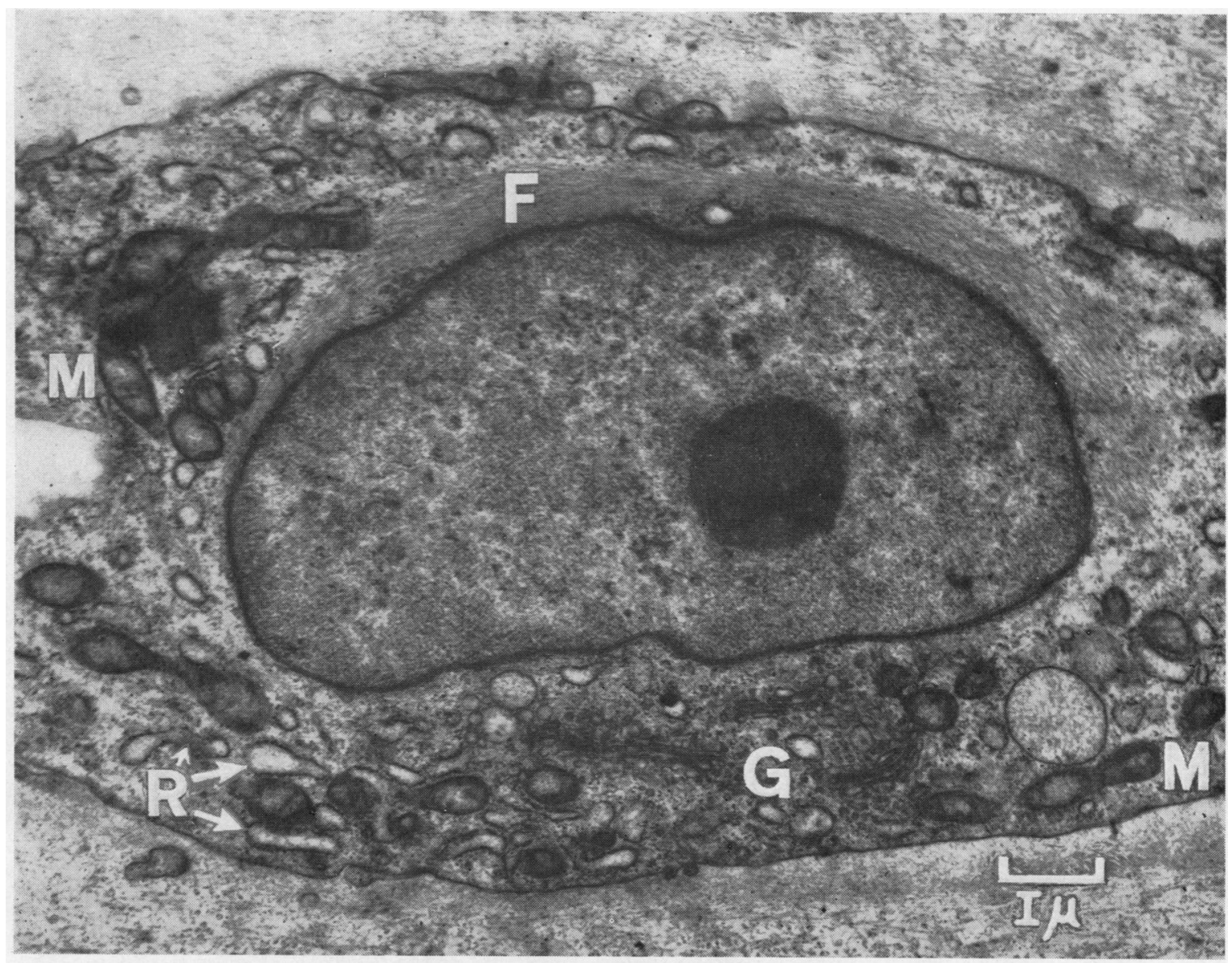

Fig. 1.-Chondrocyte with small amount of filamentous material (F) in the perinuclear zone. Note well-defined Golgi apparatus (G), much rough endoplasmic reticulum $(R)$, and mitochondria (M). $\times 13,000$.

arthritic fibrillation. They have been encountered both in the surface layer of the cartilage and in its deeper layers. In the material studied, which was all from adult subjects, no direct relationship was noticeable between the amount of the filaments and the age of the patient.

The filamentous areas of the cytoplasm are nearly always devoid of normal organelles. However they often contain small amounts of glycogen, and at times include structures which appear to be organelle remnants (Fig. 3). In a few instances the filaments surround a mitochondrion with distinct cristae, and in one instance they were seen surrounding unusual bodies of the type illustrated in Fig. 4 . In cells with filamentous areas glycogen is often also seen elsewhere in the cytoplasm, and some of the cells show one or more lipid drops.

In the majority of the cells with intracytoplasmic filaments, the filaments are present only in relatively small quantity (Figs 1 and 2). In some cells, however, unusually large accumulations of filamentous material are seen (Figs 3 and 4, overleaf). In the electronmicrographs examined no correlation was found between the general appearance of the cytoplasm and the presence or absence of small amounts of filamentous material. In cells containing only a small quantity of filaments the overall appearance of the cytoplasm varies. In a proportion of these cells the endoplasmic reticulum is well-developed, the mitochondria show well-orientated cristae, and in some instances well-formed Golgi apparatus is seen. In contrast other cells, with filaments in similar small quantity, show a cytoplasm in which the organelles tend to be reduced in number and to be degenerate.

The general appearance of the cytoplasm is more 


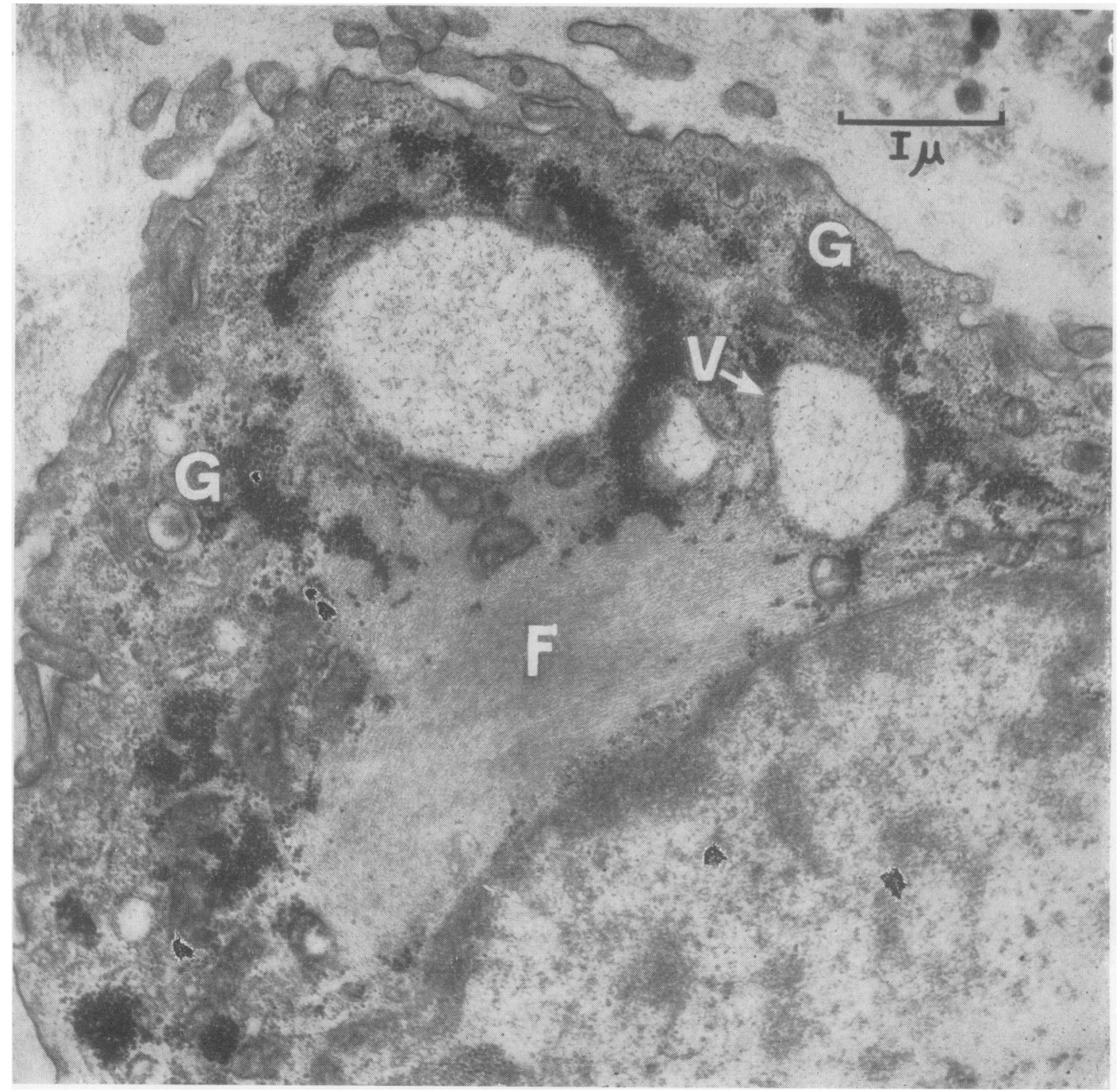

Fig. 2.-Chondrocyte with perinuclear filamentous material (F) and membrane bound vesicles (V) containing fine fibrils. Glycogen (G). containing
$\times 22,000$.

consistently affected in those cells in which an unusually large amount of filamentous material has accumulated. In such cells there is a reduction in the total number of cytoplasmic organelles because of their loss from areas replaced by the filaments; mitochondria with indistinct cristae are more frequent than in the rest of the cells studied; welldeveloped Golgi apparatus is rarely seen; and the membrane pairs of the endoplasmic reticulum are often discontinuous with dilatation of the cisternae (Figs 3 and 4).

Finely filamentous material also occurs in the matrix immediately adjacent to many of the chondrocytes. It forms a corona completely or partially surrounding the cell (Fig. 5, overleaf, p. 55). There is typically a fairly sharp demarcation between the finely filamentous material adjacent to the cell and the coarser fibres of the general matrix (Fig. 5). The fine extracellular filaments differ from the intracytoplasmic filaments in that they are less distinct in outline, more irregularly arranged, and more loosely packed (Figs 3 and 5).

Occasionally a large oval accumulation of finely filamentous material is seen in the cartilage, sharply 


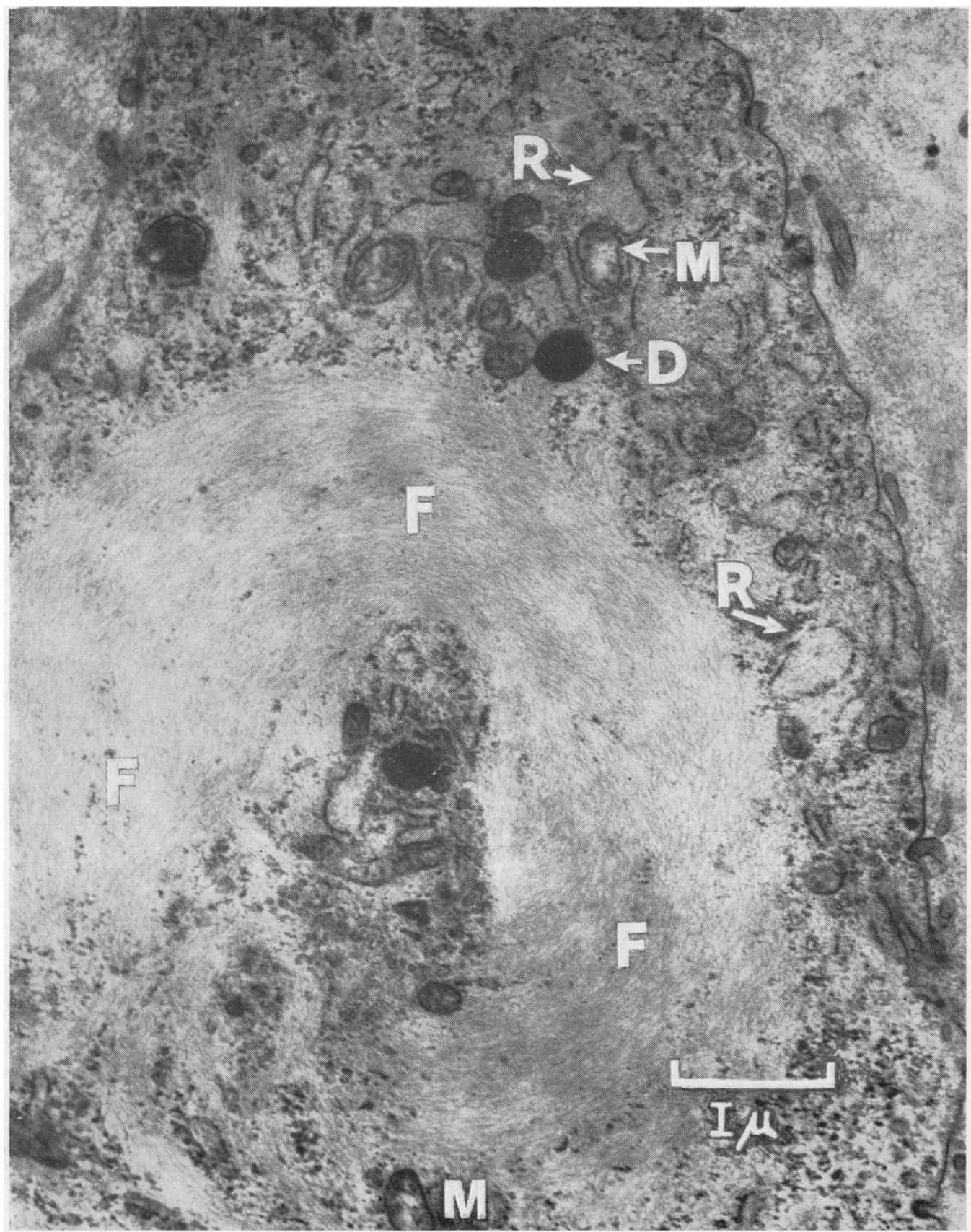

Fig. 3.-Chondrocyte showing large amount of filamentous material (F); a small amount of glycogen and some organelle remnants are embedded in it. Note discontinuity of the rough endoplasmic reticulum $(R)$, and mitochondria with indistinct

demarcated from the surrounding matrix and originally formed in the matrix or within the cell. containing debris from a disintegrated cell (Fig. 6, overleaf, p. 56). In such cases it is not possible to determine whether the filaments had

\section{Discussion}

The present study is concerned with filaments 


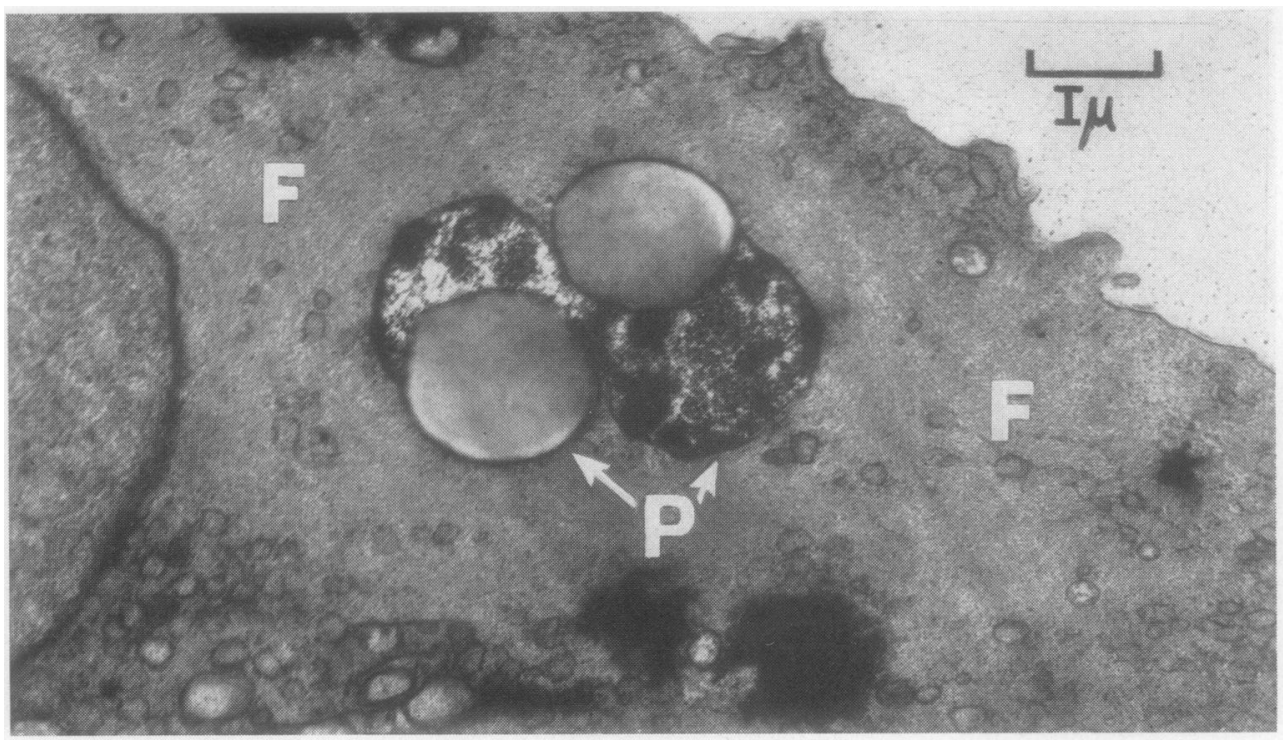

Fig. 4.-Chondrocyte with large amount of filamentous material (F) surrounding a group of unusual "paired" bodies (P). $\times 14,000$.

lying directly within the cytoplasm of chondrocytes. It does not deal with fibrillary material enclosed in membrane-bound vesicles such as that shown in Fig. 2 and described, for example, by Sheldon and Kimball (1962) in Golgi vacuoles of ear cartilage in rabbits after treatment with papain.

Instances of filaments lying directly within the cytoplasm have been reported in a number of different cell types. They have been described in peritoneal macrophages and blood monocytes by Petris, Karlsbad, and Pernis (1962), and in the Langhans' cells of the mature placenta by Lister (1963). In the case of the chondrocyte, the literature includes several reports of intracytoplasmic filaments which are not enclosed in membrane-bound vacuoles. Godman and Porter (1960) described cytoplasmic fibrils subjacent to the surface membrane of cells in developing epiphyseal cartilage of foetal rats. In chondrocytes from larval salamanders, Revel and Hay (1963) noted fine filaments in the cytoplasm "which are not unlike the tonofilaments of epithelial cells". Silberberg, Hasler, and Silberberg (1965) have found closely packed parallel intracytoplasmic fibrils in articular chondrocytes of mice treated with oestrogen. Cytoplasmic filaments in the articular cartilage of normal rabbits have been described by Barnett and others (1963) and by Palfrey and Davies (1966), and have also been illustrated by Collins and others (1965).

The present study describes cytoplasmic filaments in the chondrocytes of adult human articular cartilage. The filaments of human chondrocytes appear to be of the same type as those found in thee rabbit. They are similar in size and morphologys and, as in the rabbit, they are typically perinuclear ire situation. In contrast, the fibrils described in foetaf rat chondrocytes lie in the peripheral part of the cytoplasm subjacent to the cell membrane, and are believed by Godman and Porter (1960) to be shed from the cell into the matrix to serve as cores of the definitive matrix fibrils.

The nature and function of the filaments found in human and rabbit chondrocytes is not known. The filaments do not show the periodic banding of collagen, and their typically perinuclear situation makes it unlikely that they represent matrix fibrils which have not yet been discharged from the cell. An alternative suggestion that they contribute to the "structural strength" of the cytoplasm also has no direct evidence in its support.

From the electronmicrographs obtained during the present investigation it was possible to study the relationship of filament accumulation to the overall state of the cytoplasm in human chondrocytes. Where filaments are present only in relatively small amounts the overall state of the cytoplasm varies, but in a proportion of such cells the organelles are well-preserved. Thus the presence of filaments in small quantity is not evidence that a chondrocyte is degenerate. However, the accumulation of filaments in unusually large amounts is more consistently associated with an alteration in the general 


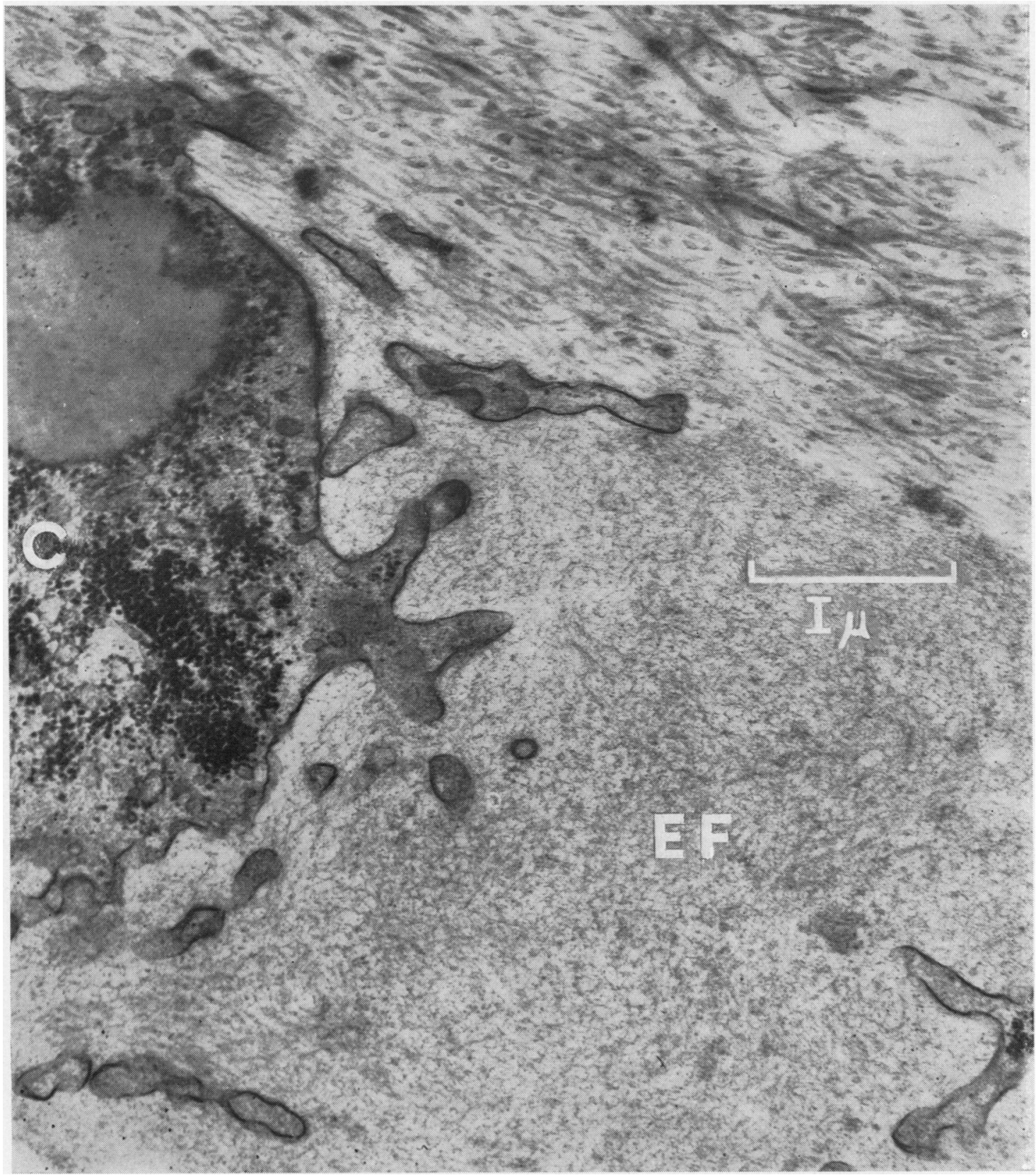

Fig. 5.-Extra-cellular filamentous material (EF): note the irregular cob-web arrangement, loose texture, and indistinct outline of the fibrils. Chondrocyte $(C)$. $\times 30,000$.

state of the cell. The total number of cytoplasmic organelles is low, and those which remain tend to be poorly-preserved. Thus chondrocytes containing a large quantity of filaments can generally be classified as "degenerate". It is, however, uncertain whether filament accumulation actually causes the chondrocyte to degenerate or whether it is simply a morphological feature of the degenerative process. 


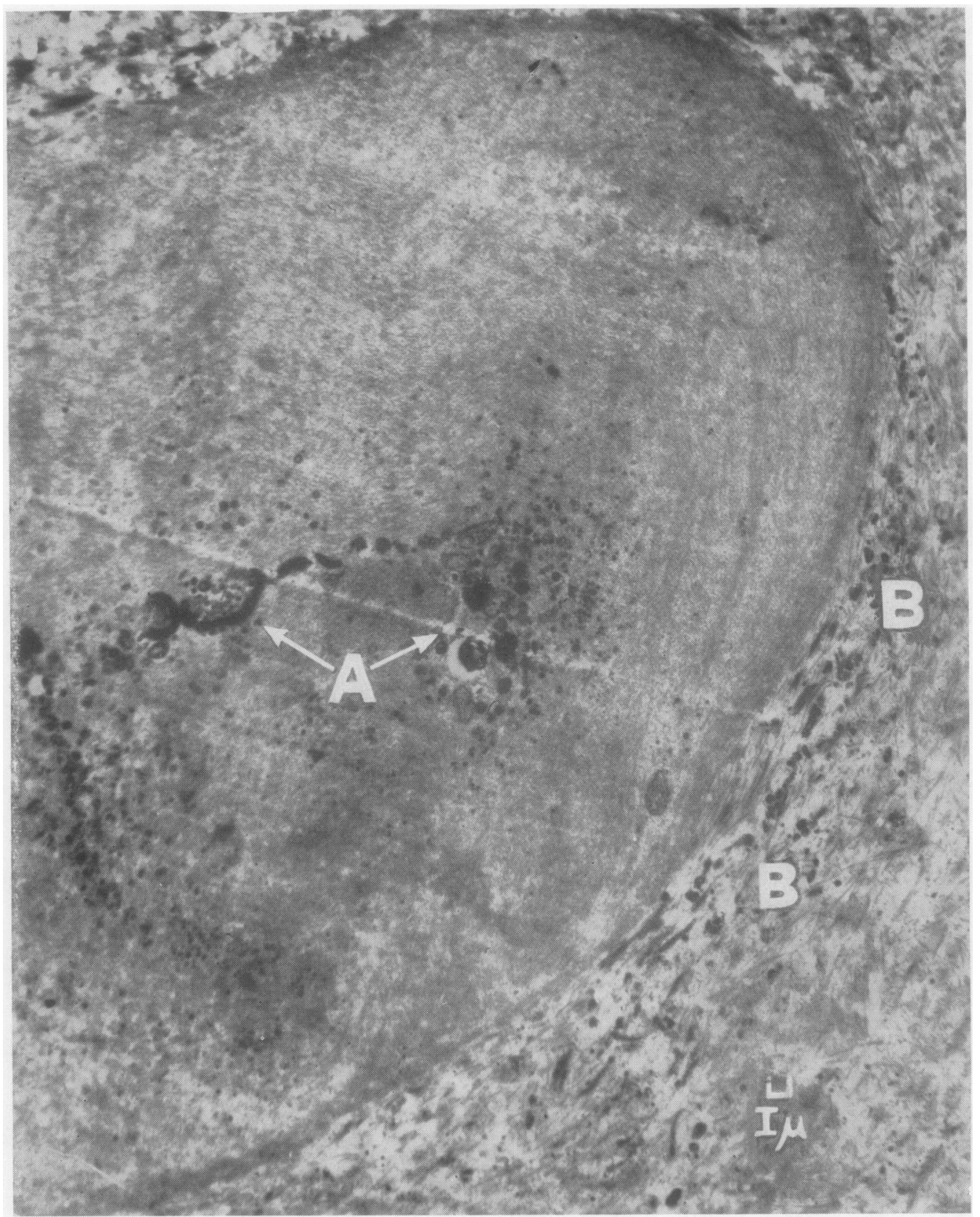

Fig. 6.-Large accumulation of fine filamentous material at the site of a disintegrated cell. Note that the material contains electron dense bodies and membranous structures which probably represent cell remnants (A). Note also electron dense bodies in the coarser fibres of the general matrix (B). $\times 3,400$.

In our electronmicrographs of adult human articular cartilage it is possible to recognize at least three patterns of cell degeneration:
(1) The first is characterized by complete dis- $\stackrel{+}{+}$ integration of the chondrocyte to form debris amongst which cell remnants and membranous 
bodies are apparent, as described in rabbit articular cartilage by Barnett and others (1963).

(2) The second is associated with accumulation of large quantities of filaments in the cytoplasm, as depicted in the present study.

(3) A third pattern, probably "degenerative", has also been noted in one of our human specimens. In this pattern the cell shows wide dilatations of the endoplasmic reticulum to form large irregular cisternae, and swelling of the mitochondria to form prominent ovoid structures with disorientated cristae; the appearance resembles one of the forms of cell degeneration observed in rabbit articular cartilage by Palfrey and Davies (1966).

\section{Summary and Conclusions}

Samples of articular cartilage from the knee joint of human adults have been studied with the electron microscope. Particular attention has been paid to the presence of filaments within the cytoplasm of the chondrocyte.

In the electronmicrographs examined many of the chondrocytes contain one or more filamentous areas. The filaments lie directly within the cytoplasm and are not enclosed in membrane-bound vacuoles. They are usually closely packed and tend to be aligned in parallel arrays. No evidence of periodicity or banding was seen. The filaments are typically perinuclear in situation; much less commonly they are seen in a more peripheral part of the cytoplasm.

Cells with filamentous areas have been found both in the surface layer of adult human articular cartilage and in its deeper layers. They have been encountered both in cartilage samples with an intact articular surface and in samples showing osteo-arthritic fibrillation.

The relationship of filament accumulation to the general state of the cytoplasm has been investigated. It is concluded that the presence of filaments in small quantity is not evidence that a chondrocyte is degenerate. However, the accumulation of filaments in unusually large amounts can generally be classified as one of the patterns of degenerative change which occur in adult human articular chondrocytes.

We are grateful to the Arthritis and Rheumatism Council for financial support and to Miss A. Malone and Mr. T. Durrant for technical assistance.

\section{REFERENCES}

Barnett, C. H., Cochrane, W., and Palfrey, A. J. (1963). Ann. rheum. Dis., 22, 389 (Age changes in articular cartilage of rabbits).

Collins, D. H., Ghadially, F. N., and Meachim, G. (1965). Ibid., 24, 123 (Intra-cellular lipids of cartilage).
Collins, D. H., and McElligott, T. F. (1960). Ibid., 19, 318 (Sulphate $\left(^{35} \mathrm{SO}_{4}\right.$ ) uptake by chondrocytes in relation to histological changes in osteo-arthritic human articular cartilage).

Davies, D. V., Barnett, C. H., Cochrane, W., and Palfrey, A. J. (1962). Ibid., 21, 11 (Electron microscopy of articular cartilage in the young adult rabbit).

Ghadially, F. N., Meachim, G., and Collins, D. H. (1965). Ibid., 24, 136 (Extra-cellular lipid in the matrix of human articular cartilage).

Godman, G. C., and Porter, K. R. (1960). J. biophys. biochem. Cytol., 8, 719 (Chondrogenesis, studied with the electron microscope).

Lister, U. M. (1963). J. Obstet. Gynaec. Brit. Emp., 70, 373 (Ultrastructure of the human mature placenta. I. The maternal surface).

Meachim, G., and Collins, D. H. (1962). Ann. rheum. Dis., 21, 45 (Cell counts of normal and osteoarthritic articular cartilage in relation to the uptake of sulphate $\left({ }^{35} \mathrm{SO}_{4}\right)$ in vitro).

- Ghadially, F. N., and Collins, D. H. (1965). Ibid, 24, 23 (Regressive changes in the superficial layer of human articular cartilage).

Palfrey, A. J., and Davies, D. V. (1966). J. Anat. (Lond.), 100, 213 (The fine structure of chondrocytes).

Petris, S. de, Karlsbad, G., and Pernis, B. (1962). J. Ultrastruct. Res., 7, 39 (Filamentous structures in the cytoplasm of normal mononuclear phagocytes).

Revel, J.-P., and Hay, E. D. (1963). Z. Zellforsch., 61, 110 (An autoradiographic and electron microscopic study of collagen synthesis in differentiating cartilage).

Sheldon, H., and Kimball, F. B. (1962). J. Cell Biol., 12, 599 (Studies on cartilage. III. The occurrence of collagen within vacuoles of the Golgi apparatus).

Silberberg, R., Hasler, M., and Silberberg, M. (1965). Amer. J. Path., 46, 289 (Submicroscopic response of articular cartilage of mice treated with estrogenic hormone).

- Silberberg, M., and Feir, D. (1964). Amer. J. Anat., 114, 17 (Life cycle of articular cartilage cells; an electron microscope study of the hip joint of the mouse).

Filaments intracytoplasmiques dans les cellules du cartilage articulaire de l'homme adulte

RÉSUMÉ

On a étudié au microscope électronique des prélèvements de cartilage articulaire obtenu à partir de genoux d'homme adulte. On a accordé un intérêt particulier à la présence de filaments au sein du cytoplasme des chondrocytes.

Les chondrocytes ainsi examinés contenaient une ou plusieurs aires filamenteuses. Les filaments se trouvaient directement à l'intérieur du cytoplasme et non pas contenus dans des vacuoles limitées par une membrane. Ils étaient habituellement en paquets bien serrés et tendaient à s'aligner en rangées parallèles. On n'a observé ni périodicité ni disposition en faisceaux. Les filaments siégeaient typiquement autour du noyau, beaucoup moins souvent vers la périphérie du cytoplasme. 
On a trouvé des cellules présentant des aires filamenteuses aussi bien dans la couche superficielle de cartilage articulaire d'homme adulte que dans ses couches plus profondes. On les a rencontrées dans les prélèvements où la surface articulaire était intacte et dans ceux où l'on avait noté une fibrillation d'origine ostéo-arthrosique.

On a étudié le rapport entre l'accumulation des filaments et l'état général du cytoplasme. On a conclu que la présence de filaments en petite quantité n'est pas l'indice de la dégénérescence d'un chondrocyte. Cependant l'accumulation de filaments en quantité anormalement grande peut être interprêtée comme une manifestation de lésion dégénérative des chondrocytes chez l'homme adulte.

Filamentos intracitoplásmicos en las células del cartílago articular del hombre adulto

Sumario

Se estudiaron al microscopio electrónico cortes del cartílago articular tomado de la rodilla del hombre adulto. Se presta atención particular a la presencia de filamentos en el seno del citoplasma de los condrocitos.
Los condrocitos así examinados contienen una o más zonas filamentosas. Los filamentos se encuentran directamente en el interior del citoplasma y no están incluidos en vacuolas limitadas por una membrana. Generalmente se les ve agrupados estrechamente con tendencia a alinearse en formaciones paralelas. No se observa periodicidad o disposición fascicular. Típicamente, los filamentos se situan alrededor del núcleo o, menos frecuentemente, hacia la perifería del citoplasma.

Se hallan células con zonas filamentosas tanto en la capa superficial del cartílago articular del hombre adulto como en sus estructuras más profundas. Se les ve no sólo en los cortes de la superficie articular intacta, sino también en los cortes con fibrilación osteoartrósica presente.

Se estudió la relación entre la acumulación de filamentos y el estado general del citoplasma. Se concluye que la presencia de filamentos en pequeñas cantidades no constituye un indicio de degeneración condrocítica. Sin embargo, la acumulación de filamentos en cantidades estimables puede interpretarse como una de las manifestaciones de degeneración de los condrocitos del hombre adulto. 